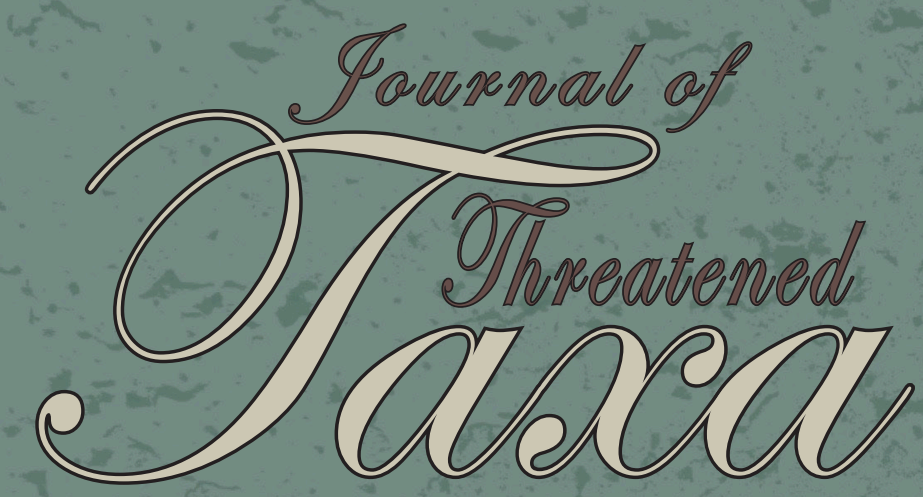

Building evidence for conservation globally
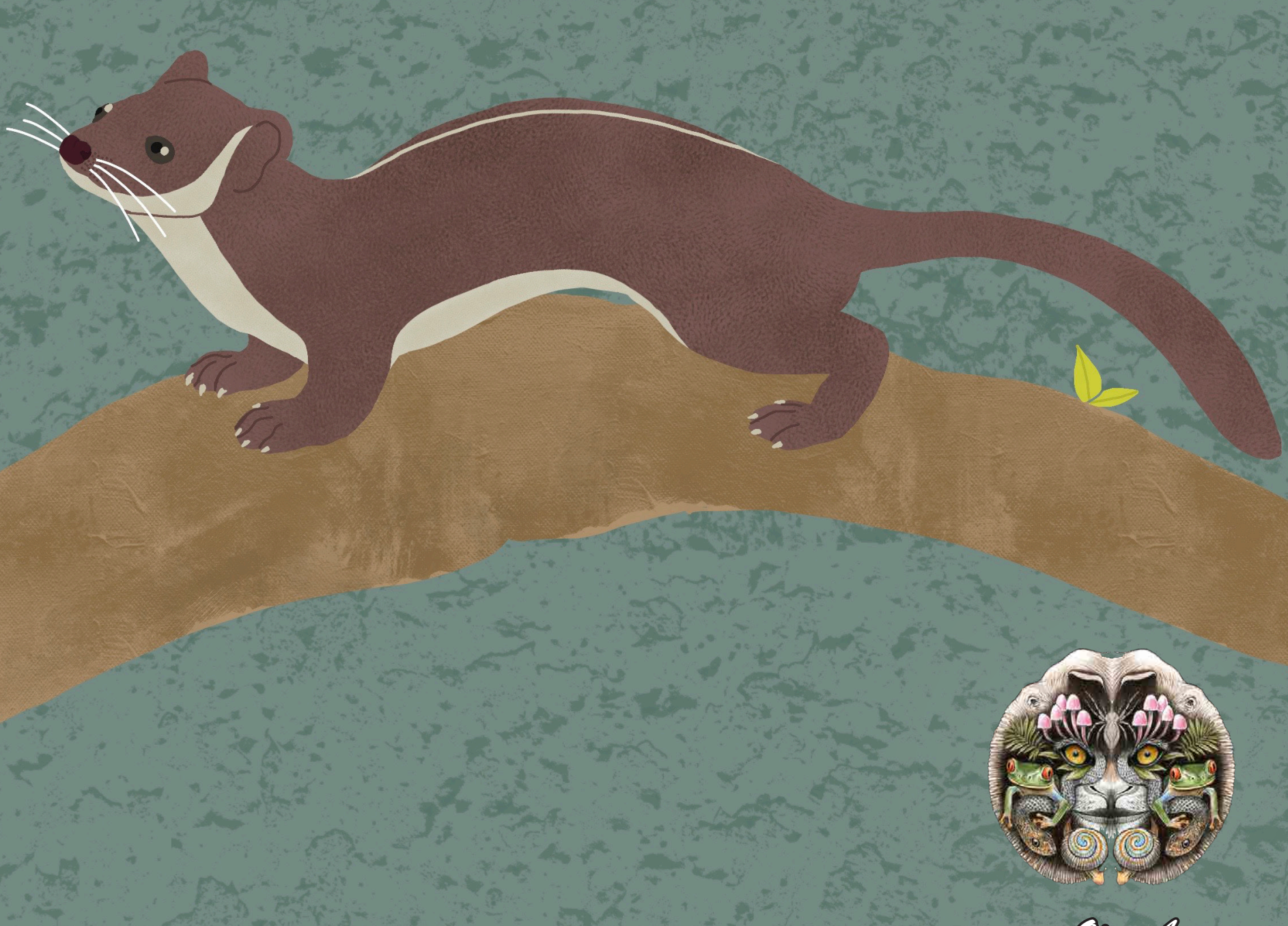

Qpecosecess

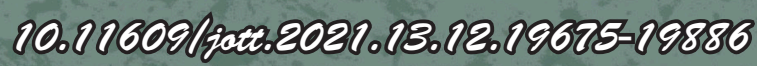
cocosurthreatecredtassararg

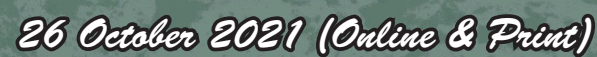

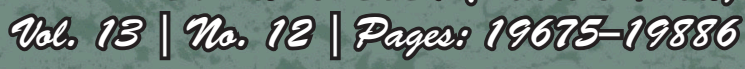




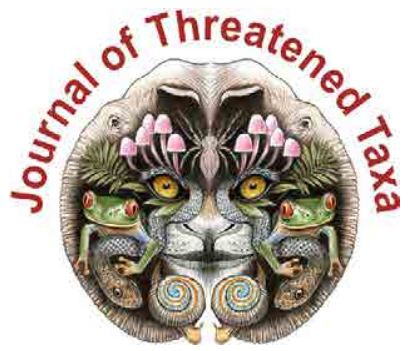

ISSN $0974-7907$ (Online); ISSN $0974-7893$ (Print)

Publisher

Host

Wildlife Information Liaison Development Society

www.wild.zooreach.org

Zoo Outreach Organization www.zooreach.org

No. 12, Thiruvannamalai Nagar, Saravanampatti - Kalapatti Road, Saravanampatti, Coimbatore, Tamil Nadu 641035, India

Ph: +91 9385339863 | www.threatenedtaxa.org

Email: sanjay@threatenedtaxa.org

EDITORS

\section{Founder \& Chief Editor}

Dr. Sanjay Molur

Wildlife Information Liaison Development (WILD) Society \& Zoo Outreach Organization (ZOO)

12 Thiruvannamalai Nagar, Saravanampatti, Coimbatore, Tamil Nadu 641035, India

\section{Deputy Chief Edito}

Dr. Neelesh Dahanukar

Noida, Uttar Pradesh, India

\section{Managing Editor}

Mr. B. Ravichandran, WILD/ZOO, Coimbatore, India

\section{Associate Editors}

Dr. Mandar Paingankar, Government Science College Gadchiroli, Maharashtra 442605, India

Dr. Ulrike Streicher, Wildlife Veterinarian, Eugene, Oregon, USA

Ms. Priyanka lyer, ZOO/WILD, Coimbatore, Tamil Nadu 641035, India

(Dr. B. Daniel, $200 / \mathrm{WILD}$, Coimbatore, Tamil Nadu 641035, India

\section{Editorial Board}

Dr. Russel Mittermeier

Executive Vice Chair, Conservation International, Arlington, Virginia 22202, USA

\section{Prof. Mewa Singh Ph.D., FASc, FNA, FNASc, FNAPsy}

Ramanna Fellow and Life-Long Distinguished Professor, Biopsychology Laboratory, and Institute of Excellence, University of Mysore, Mysuru, Karnataka 570006, India; Honorary Professor, Jawaharlal Nehru Centre for Advanced Scientific Research, Bangalore; and Adjunct Professor, National Institute of Advanced Studies, Bangalore

\section{Stephen D. Nash}

Scientific Illustrator, Conservation International, Dept. of Anatomical Sciences, Health Sciences Center, T-8, Room 045, Stony Brook University, Stony Brook, NY 11794-8081, USA

\section{Dr. Fred Pluthero}

Toronto, Canada

\section{Dr. Priya Davidar}

Sigur Nature Trust, Chadapatti, Mavinhalla PO, Nilgiris, Tamil Nadu 643223, India

\section{Dr. Martin Fisher}

Senior Associate Professor, Battcock Centre for Experimental Astrophysics, Cavendish

Laboratory, JJ Thomson Avenue, Cambridge CB3 OHE, UK

\section{Dr. John Fellowe}

Honorary Assistant Professor, The Kadoorie Institute, 8/F, T.T. Tsui Building, The University of Hong Kong, Pokfulam Road, Hong Kong

\section{Prof. Dr. Mirco Solé}

Universidade Estadual de Santa Cruz, Departamento de Ciências Biológicas, Vice-coordenado do Programa de Pós-Graduação em Zoologia, Rodovia Ilhéus/Itabuna, Km 16 (45662-000)

Salobrinho, Ilhéus - Bahia - Brasil

\section{Dr. Rajeev Raghavan}

Professor of Taxonomy, Kerala University of Fisheries \& Ocean Studies, Kochi, Kerala, India

\section{English Editors}

Mrs. Mira Bhojwani, Pune, India

Dr. Fred Pluthero, Toronto, Canad

Mr. P. Ilangovan, Chennai, India

Web Maintenance

Mrs. Latha G. Ravikumar, ZOO/WILD, Coimbatore, India

\section{Typesetting}

Mr. Arul Jagadish, ZOO, Coimbatore, India

Mrs. Radhika, ZOO, Coimbatore, India

Mrs. Geetha, ZOO, Coimbatore India

\section{Fundraising/Communications}

Mrs. Payal B. Molur, Coimbatore, India

Subject Editors 2018-2020

Fungi

Dr. B. Shivaraju, Bengaluru, Karnataka, India

Dr. R.K. Verma, Tropical Forest Research Institute, Jabalpur, India

Dr. Vatsavaya S. Raju, Kakatiay University, Warangal, Andhra Pradesh, India

Dr. M. Krishnappa, Jnana Sahyadri, Kuvempu University, Shimoga, Karnataka, India

Dr. K.R. Sridhar, Mangalore University, Mangalagangotri, Mangalore, Karnataka, India

Dr. Gunjan Biswas, Vidyasagar University, Midnapore, West Bengal, India

Plants

Dr. G.P. Sinha, Botanical Survey of India, Allahabad, India

Dr. N.P. Balakrishnan, Ret. Joint Director, BSI, Coimbatore, India

Dr. Shonil Bhagwat, Open University and University of Oxford, UK

Prof. D.J. Bhat, Retd. Professor, Goa University, Goa, India

Dr. Ferdinando Boero, Università del Salento, Lecce, Italy

Dr. Dale R. Calder, Royal Ontaro Museum, Toronto, Ontario, Canada

Dr. Cleofas Cervancia, Univ. of Philippines Los Baños College Laguna, Philippines

Dr. F.B. Vincent Florens, University of Mauritius, Mauritius

Dr. Merlin Franco, Curtin University, Malaysia

Dr. V. Irudayaraj, St. Xavier's College, Palayamkottai, Tamil Nadu, India

Dr. B.S. Kholia, Botanical Survey of India, Gangtok, Sikkim, India

Dr. Pankaj Kumar, Kadoorie Farm and Botanic Garden Corporation, Hong Kong S.A.R., China

Dr. V. Sampath Kumar, Botanical Survey of India, Howrah, West Bengal, India

Dr. A.J. Solomon Raju, Andhra University, Visakhapatnam, India

Dr. Vijayasankar Raman, University of Mississippi, USA

Dr. B. Ravi Prasad Rao, Sri Krishnadevaraya University, Anantpur, India

Dr. K. Ravikumar, FRLHT, Bengaluru, Karnataka, India

Dr. Aparna Watve, Pune, Maharashtra, India

Dr. Qiang Liu, Xishuangbanna Tropical Botanical Garden, Yunnan, China

Dr. Noor Azhar Mohamed Shazili, Universiti Malaysia Terengganu, Kuala Terengganu, Malaysia Dr. M.K. Vasudeva Rao, Shiv Ranjani Housing Society, Pune, Maharashtra, India

Prof. A.J. Solomon Raju, Andhra University, Visakhapatnam, India

Dr. Mandar Datar, Agharkar Research Institute, Pune, Maharashtra, India

Dr. M.K. Janarthanam, Goa University, Goa, India

Dr. K. Karthigeyan, Botanical Survey of India, India

Dr. Errol Vela, University of Montpellier, Montpellier, France

Dr. P. Lakshminarasimhan, Botanical Survey of India, Howrah, India

Dr. Larry R. Noblick, Montgomery Botanical Center, Miami, USA

Dr. K. Haridasan, Pallavur, Palakkad District, Kerala, India

Dr. Analinda Manila-Fajard, University of the Philippines Los Banos, Laguna, Philippines

Dr. P.A. Sinu, Central University of Kerala, Kasaragod, Kerala, India

Dr. Afroz Alam, Banasthali Vidyapith (accredited A grade by NAAC), Rajasthan, India

Dr. K.P. Rajesh, Zamorin's Guruvayurappan College, GA College PO, Kozhikode, Kerala, India

Dr. David E. Boufford, Harvard University Herbaria, Cambridge, MA 02138-2020, USA

Dr. Ritesh Kumar Choudhary, Agharkar Research Institute, Pune, Maharashtra, India

Dr. Navendu Page, Wildlife Institute of India, Chandrabani, Dehradun, Uttarakhand, India

Invertebrates

Dr. R.K. Avasthi, Rohtak University, Haryana, India

Dr. D.B. Bastawade, Maharashtra, India

Dr. Partha Pratim Bhattacharjee, Tripura University, Suryamaninagar, India

Dr. Kailash Chandra, Zoological Survey of India, Jabalpur, Madhya Pradesh, India

Dr. Ansie Dippenaar-Schoeman, University of Pretoria, Queenswood, South Africa

Dr. Rory Dow, National Museum of natural History Naturalis, The Netherlands

Dr. Brian Fisher, California Academy of Sciences, USA

Dr. Richard Gallon, llandudno, North Wales, LL30 1UP

Dr. Hemant V. Ghate, Modern College, Pune, India

Dr. M. Monwar Hossain, Jahangirnagar University, Dhaka, Bangladesh

Mr. Jatishwor Singh Irungbam, Biology Centre CAS, Branišovská, Czech Republic

Dr. lan J. Kitching, Natural History Museum, Cromwell Road, UK

Dr. George Mathew, Kerala Forest Research Institute, Peechi, India

Dr. John Noyes, Natural History Museum, London, UK

For Focus, Scope, Aims, and Policies, visit https://threatenedtaxa.org/index.php/JoTT/aims_scope
For Article Submission Guidelines, visit https://threatenedtaxa.org/index.php/JoTT/about/submissions
For Policies against Scientific Misconduct, visit https://threatenedtaxa.org/index.php/JoTT/policies_various

continued on the back inside cover 


\title{
First report of Scipinia horrida (Stål) (Heteroptera: Reduviidae) from Assam, with comments on related genus Irantha Stål
}

\author{
Anjana Singha Naorem ${ }^{1} \mathbb{D}$, Santana Saikia ${ }^{2} \mathbb{D}$, Anandita Buragohain ${ }^{3} \mathbb{D}$, Rubina Azmeera Begum ${ }^{4} \mathbb{D}$, \\ Swapnil S. Boyane ${ }^{5}(\mathbb{D})$ \& Hemant V. Ghate ${ }^{6}(\mathbb{C})$ \\ ${ }^{1-4}$ Department of Zoology, Cotton University, Panbazar, Guwahati, Assam 781001, India. \\ 5,6 Post-Graduate Research Centre, Department of Zoology, Modern College of Arts, Science and Commerce (Autonomous), Shivajinagar, \\ Pune, Maharashtra 411005, India. \\ ${ }^{5}$ Present Address: Ashoka Trust for Research in Ecology and the Environment, Royal Enclave, Srirampura, Jakkur, Bengaluru, \\ Karnataka 560064, India. \\ ${ }^{1}$ anjanasingha@cottonuniversity.ac.in, ${ }^{2}$ santanasaikia7@gmail.com, ${ }^{3}$ anagohain30@gmail.com, ${ }^{4}$ begumrubinaazmeera@gmail.com, \\ ${ }^{5}$ boyane.swapnil@gmail.com, ${ }^{6}$ hemantghate@gmail.com (corresponding author)
}

Abstract: Presence of reduviid bugs Scipinia horrida (Stål, 1861) and Irantha sp., belonging to the family Reduviidae and subfamily Harpactorinae, is reported here for the first time from Guwahati, Assam. We provide images and comparative comments on these two bugs.

Keywords: Assassin bugs, Harpactorinae, Iranthini.

Four specimens of small reduviid bugs collected in Guwahati (Assam, India) were identified as Scipinia horrida (Stål, 1859) (three specimens) and Irantha sp. (one specimen) based on keys in Distant (1904). Distant (1904) had placed these two genera under 'division' Polididusaria (= Polididini Distant, 1904) stating that 'In this division the anterior femora are granulate, generally nodose or nodulose, and always spinous'. The genus Irantha Stål, 1861 was separated from closely related genus Scipinia Stål, 1861 on the basis of the length of the first two visible segments of labium. Thus the first joint of labium is longer than second in Irantha while the first and second joints are subequal in Scipinia.

Maldonado-Capriles (1990) included eight species under Scipinia in the Catalogue, of which only one, namely $S$. horrida is known from India. Huang et al. (2007) reviewed Scipinia and described one new species from China, thus the total number of species under this genus stands at nine. Ambrose (2006) listed S. horrida and stated its distribution as: China, India, Indonesia (Java), Myanmar, Philippines, and Sri Lanka; this list also included names of places from southern India and Calcutta (=Kolkata). Huang et al. (2007) also listed Sikkim as another locality along with several places from China. Apparently, S. horrida has not so far been recorded from Assam. Originally described as Sinea horrida Stål, 1859, the species was then transferred to the genus Scipinia Stål, 1861 of which it is the type species (Maldonado-

Citation: Naorem, A.S., S. Saikia, A. Buragohain, R.A. Begum, S.S. Boyane \& H.V. Ghate (2021). First report of Scipinia horrida (Stål) (Heteroptera: Reduviidae) from Assam, with comments on related genus Irantha Stål. Journal of Threatened Taxa 13(12): 19824-19830. https://doi.org/10.11609/jott.7124.13.12.19824-19830

Copyright: (c) Naorem et al. 2021. Creative Commons Attribution 4.0 International License. JoTT allows unrestricted use, reproduction, and distribution of this article in any medium by providing adequate credit to the author(s) and the source of publication.

Funding: Department of Biotechnology, India. Project No. BT/IN/Indo-US/Foldscope/39/2015

Competing interests: The authors declare no competing interests.

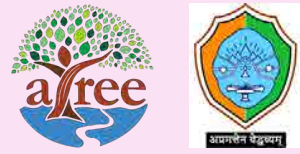

Acknowledgements: Authors are thankful to the Department of Biotechnology, India for all the financial support under the project BT/IN/Indo-US/ Foldscope/39/2015. S. Boyane would like to express gratitude to the Department of Biotechnology (Govt. of India) for financial support provided via a major research project on "Bio-resource and Sustainable livelihoods in North East India (BT/01/17/NE/TAX). A.S. Naorem is also thankful to Cotton University authorities for all the institutional support and facilities. We gratefully acknowledge Gunvi Lindberg and Swedish Museum of Natural History, Stockholm, Sweden, for providing images of the type of Irantha and for permission to use those (Attribution: CC BY-NC 3.0). H.V. Ghate is indebted to the authorities of Modern College for facilities and encouragement. 
Capriles 1990).

Three species of Irantha are known from India: (i) I. armipes (Stål, 1855), (ii) I. consobrina Distant, 1904, and (iii) I. pepparai Livingstone \& Ravichandran, 1988; all these three species have been recorded from southern India (Ambrose 2006). We are, however, not aware of any Irantha recorded from Assam. Irantha armipes was originally described as Harpactor armipes by Stål (1855) and is the type species of the genus Irantha Stål, 1861; only three species were listed by MaldonadoCapriles (1990) (namely I. armipes, I. consobrina, and I. bramarbas Breddin, 1903) without reference to I. pepparai. Chen et al. (2005) described a new species of Irantha from China, Irantha nigrina Chen, Zhao \& Cai, 2005 which then becomes the fifth species under this genus.

Both, S. horrida and Irantha sp. belong to the subfamily Harpactorinae, the largest subfamily of Reduviidae, with over 2,800 described species under 320 genera (Weirauch et al. 2014). Most of the members of this family are predators and play an important role in the ecosystem.

The genera Scipinia and Irantha, and the included species Scipinia horrida as well as Irantha armipes, have been redescribed in detail with several illustrations (see Chen et al. 2005; Huang et al. 2007), so here we are only giving brief comments and photographic illustrations of the two species. Comparative images of both these species are given here. The specimen of Irantha was collected in a spider web and because the genital region was damaged, we are treating that as Irantha sp. close to I. armipes. We are also providing some images of the type specimen of $I$. armipes, preserved in the Swedish Museum of Natural History, Stockholm, Sweden (NHRS). In the recent work Zhao (2008) placed Irantha and Scipinia under the new tribe Iranthini.

\section{METHODS}

Scipinia specimens were collected from pigeon pea plantation of Horticulture Research Station, Guwahati, by hand picking method, killed with ethyl acetate and preserved in ethanol. For Irantha sp., a single damaged individual was found dead in a spider web. Specimens were studied under the Leica stereozoom (MZ6) and photographs were taken with an attached Canon PowerShot S50 camera. Several images of the bugs were stacked using Combine ZM software and the images were processed with Adobe Photoshop CS5. Measurements were done with Erma stage and ocular micrometre. For the preparation of male genitalia, the pygophore was separated from body by dipping the abdomen in hot $\mathrm{KOH}$ for 3-5 minutes and the insect was briefly rinsed with $5 \%$ acetic acid, washed in $70 \%$ alcohol and dry mounted subsequently. Different views of pygophore were first photographed and then the phallus was removed after treating the pygophore in hot $\mathrm{KOH}$ further for 5 minutes. Pygophore and phallus were photographed under Leica as mentioned above.

Material examined: Scipinia horrida two males, one female; Irantha sp. one male (abdomen damaged). Both species were collected in Assam (Assam Insects nos. 16 to 18 (Scipinia), Assam Insects no. 19 (Irantha)). Specimens are currently preserved in Modern College, Pune.

\section{TAXONOMY}

Reduviidae Latreille, 1807

Harpactorinae Amyot \& Audinet-Serville, 1843.

Iranthini Zhao, 2008

Scipinia Stål, 1861 (type species Sinea horrida Stål, 1859)

Scipinia horrida (Stål, 1859)

For various other synonyms, please refer to MaldonadoCapriles (1990).

Brief description: Total length: Male $11 \mathrm{~mm}$, female $11.5 \mathrm{~mm}$. Colour and vestiture: Body mostly ochraceous; dorsally a narrow median region of anteocular and major postocular region of head, very narrow median region of anterior lobe of pronotum, lateral margins of scutellum, clavus and membrane of hemelytra, thoracic sterna, especially mesosternum, dark brown; lateral area of abdomen with blackish patches in basal half; legs with femora reddish-ochraceous, tibia and tarsi dark brown. Whole body covered with small, adpressed, yellowish setae and some scattered, long, transluscent setae, which are more numerous and conspicuous on legs (Image 1A); head and thoracic region densely pubescent on ventral side (Image $1 C, F)$.

Structure: Head cylindrical; anteocular slightly shorter than postocular (much shorter than postocular if neck is included); deep transverse sulcus at level of eyes as seen laterally. Head dorsally bears three pairs of long spines: one pair near antennal base, one above eyes and one behind eyes, along with many (about 10 pairs) small spines in between long spines as well as in posterior part of head. Eyes globular, with its inferior margin not reaching ventral margin of head; ocelli widely separated and also far from eyes, situated near base of third spine on head (Image 1B,D). Antennae four segmented, first antennomere longest, remaining subequal. Labium with first visible segment slightly longer than visible segment II, visible segment III smallest. Thorax with pronotum almost hexagonal in shape, broadest in middle with 


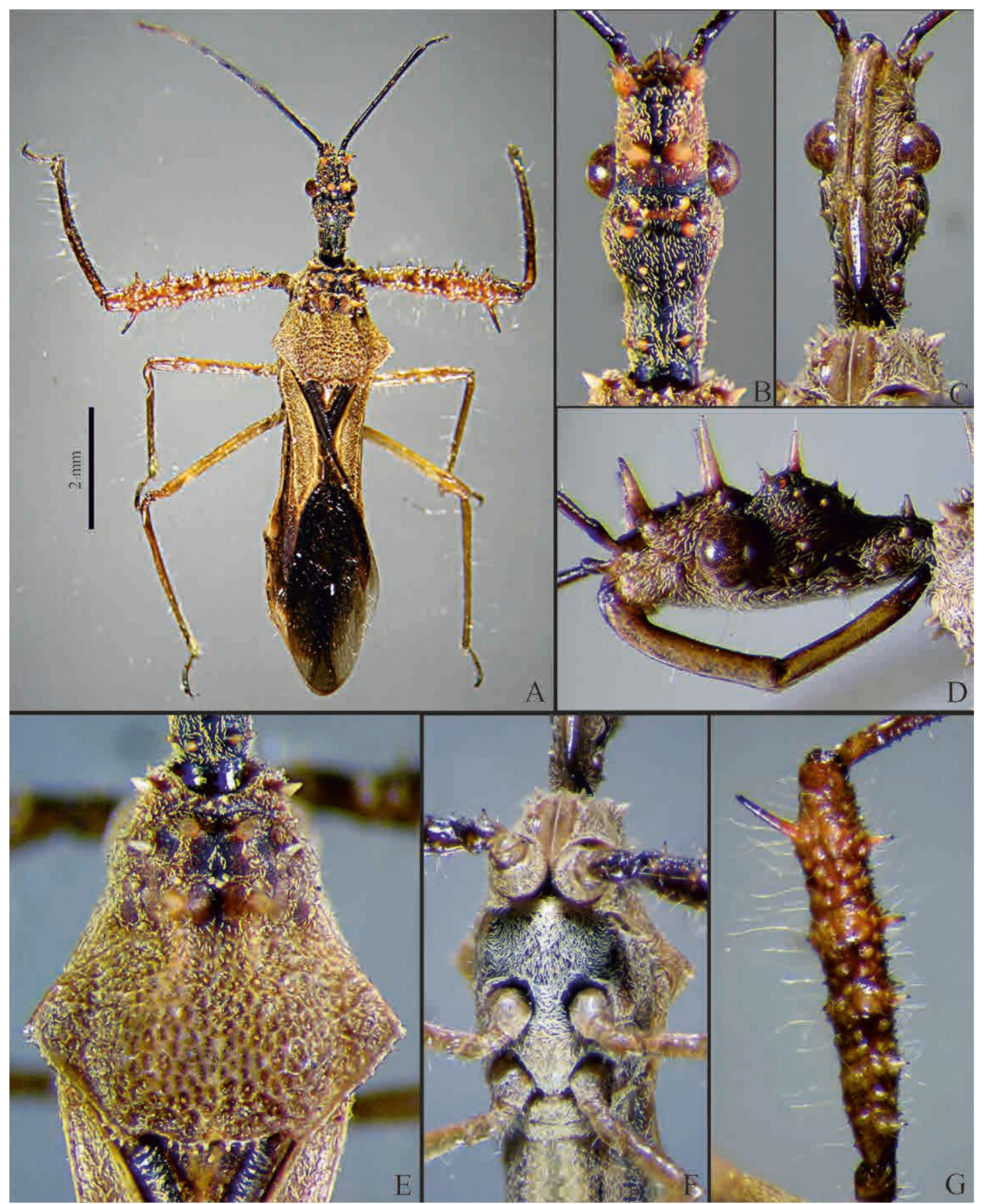

Image 1. Scipinia horrida: A-Dorsal habitus | B, C \& D-Head in dorsal, ventral and lateral view, respectively | E-Pronotum in dorsal view | F-Thoracic sterna in ventral view | G-Fore femur. (c) H.V. Ghate.

angular humeral angles, narrowed at anterior and posterior margins, anterior margin straight, posterior margin strongly sinuate over scutellum; pronotum divided into small anterior and large posterior lobe; anterior lobe with many blunt tubercular spines and two pairs of large spines, posterior pair with $Y$ shaped or bifurcate spines (Image 2A); posterior lobe strongly rugulose with beehive like pattern of deep punctures
(Image 1E). Scutellum is very small and triangular. Abdomen, in case of male, is slim and slender, with almost triangular visible part of pygophore, in ventral view (Image 2B); in case of female, abdomen is dilated in fourth and fifth segment.

Legs with fore femur moderately incrassate, with numerous pale tubercles, armed with whorls of fine spines, one dorsoapical spine longest, projected 

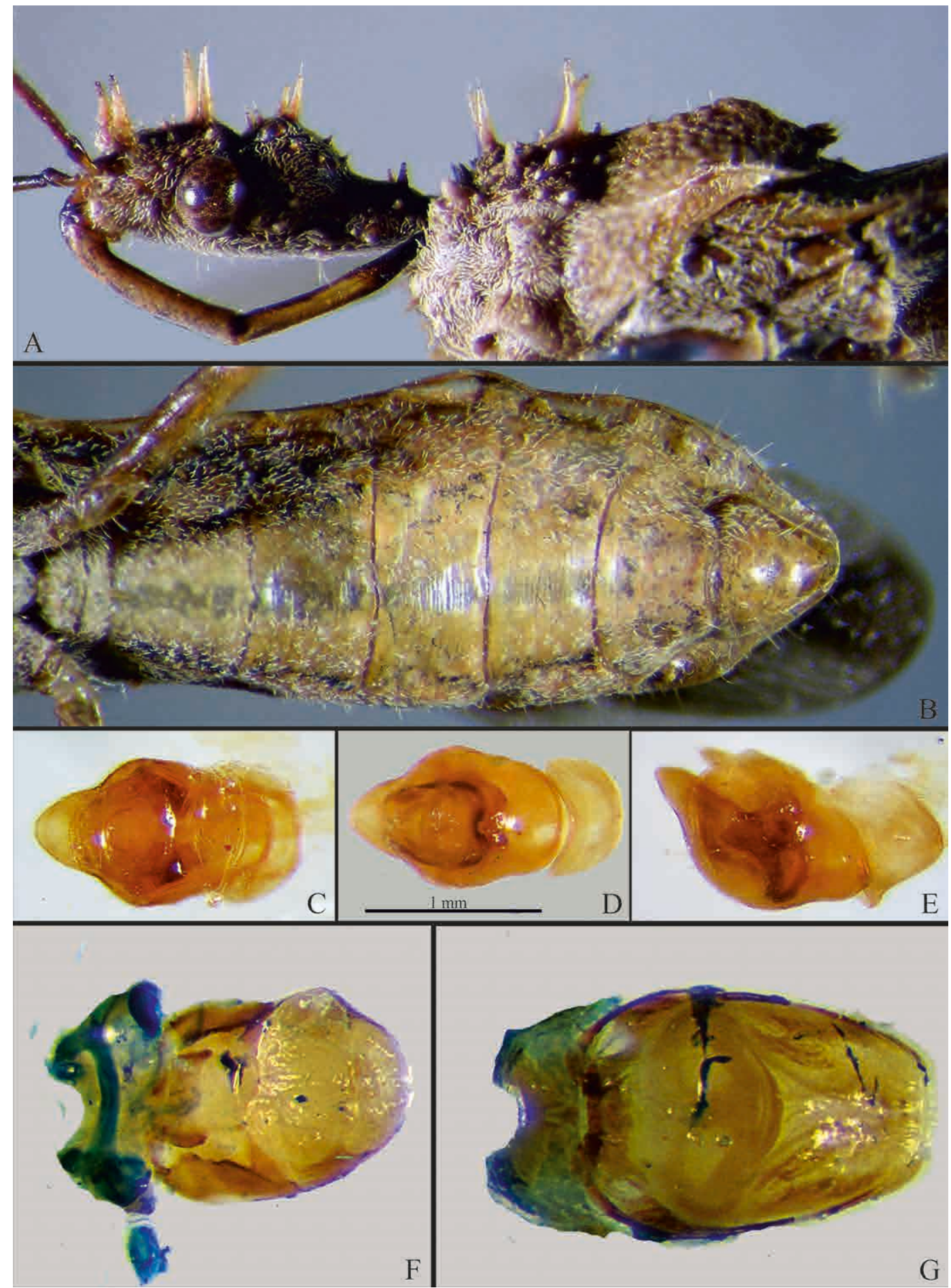

Image 2. Scipinia horrida: A-Lateral view of head and pronotum | B-Ventral view of abdomen | C-E-Pygophore in dorsal, ventral and lateral view, respectively | F \& G-Phallus in dorsal and ventral view, respectively. ( $)$ H.V. Ghate.

outwardly (Image 1A,G); tibia thin and slightly curved inward in distal one third, with many small tubercles ventrally and an apical large and triangular tubercle; tarsus three segmented, claws relatively long. Mid- and hind legs with some long spine like setae, femora slightly nodulose; mid legs shortest. Hemelytra pass beyond tip of abdomen.

Pygophore elongate oval, as shown here in dorsal, ventral and lateral views (Image 2C-E); parameres absent. Phallus in dorsal and ventral view is also 


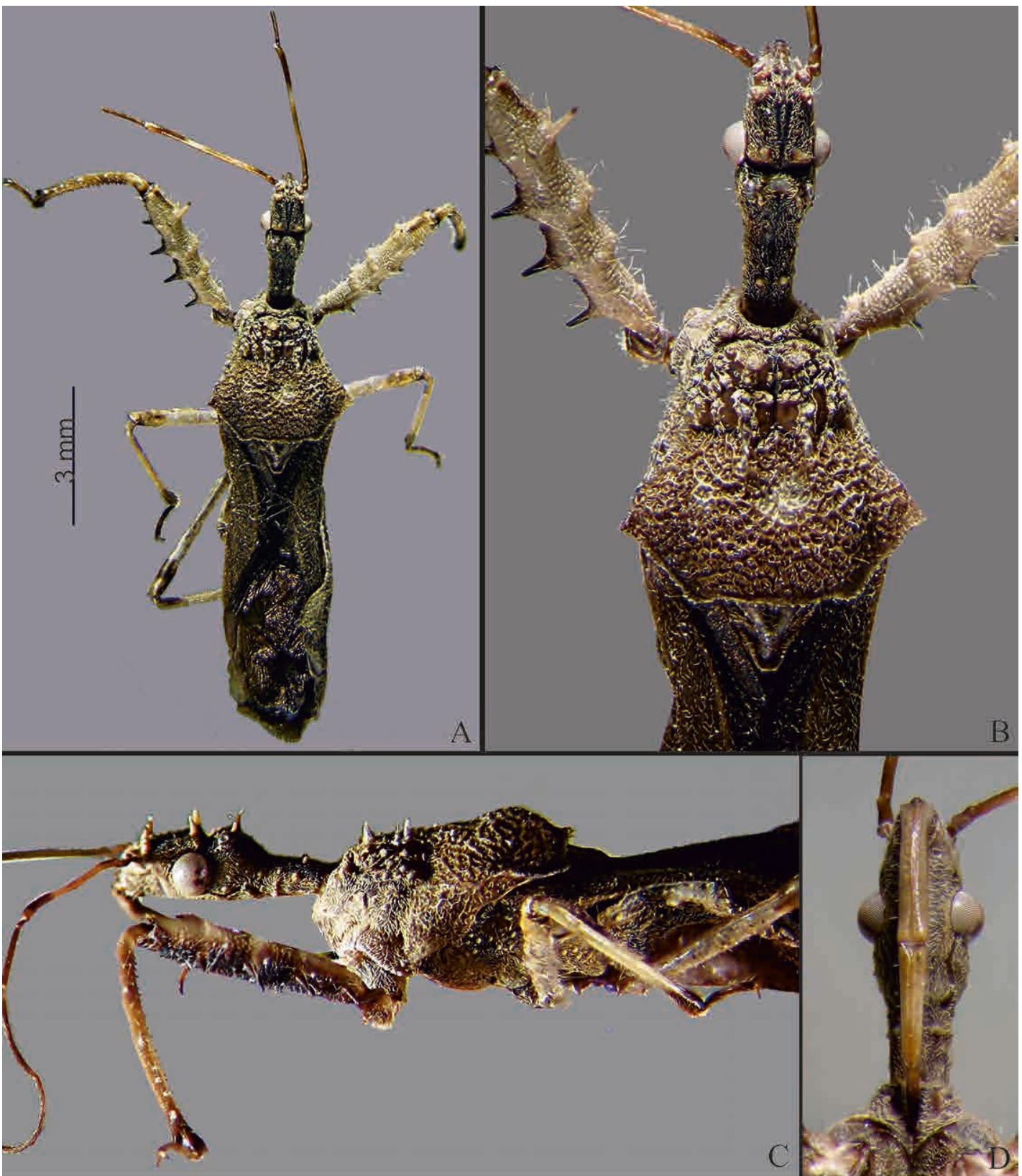

Image 3. Irantha sp.: A-Dorsal habitus | B-Details of head and pronotum in dorsal view | C-Lateral view | D-Ventral view of head. @ H.V. Ghate.

illustrated (Image 2F,G).

Distribution: India: (Andaman \& Nicobar Islands (South Andaman), Sikkim, Tripura, Karnataka, Tamil Nadu, and West Bengal, Meghalaya), China, Indonesia, Myanmar, Philippines, and Sri Lanka (Distant 1904, Ambrose 2006, Bhagyasree 2018, Huang et al. 2007, Mukherjee \& Hassan 2016)

\section{Irantha Stål, 1861}

Type species by monotypy: Harpactor armipes Stål, 1855.

For various other synonyms of Irantha armipes, refer to Maldonado-Capriles (1990).

Specimen examined: Irantha sp. close to I. armipes (Stål, 1855) (total length: $12 \mathrm{~mm}$, male).

Comments: Irantha sp. illustrated here has deceptively similar appearance to Scipinia horrida, what could possibly lead to a misidentification. However, careful observations revealed the following significant 


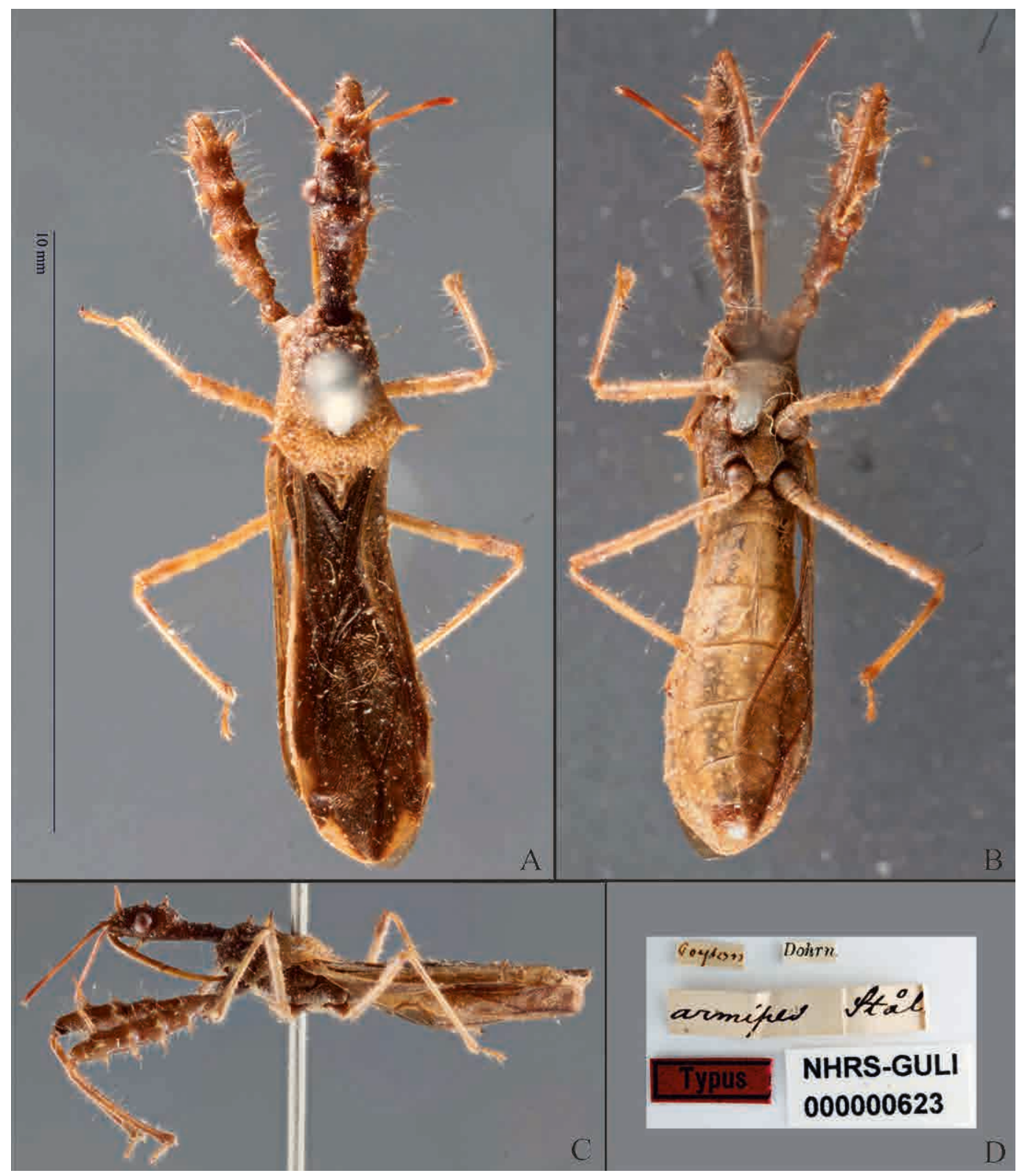

Image 4. Habitus of type specimen of Irantha armipes: A-Dorsal view | B-Ventral view | C-Lateral view | D-Labels. () The Swedish Museum of Natural History; photographed by Gunvi Lindberg, 2019.

differences or diagnostic characters.

Irantha has longer neck like region than Scipinia; fore femur in Irantha is with many long and strong spines (Image 3A), in Scipinia fore femur is with many small and only one long subapical spine (Image 1G); first visible labial segment is distinctly longer than second in Irantha (Image 3D) and it is only slightly longer than second in Scipinia (Image 1C,D); pronotal humeral angles are sharp in Irantha (Image 3B) but are slightly blunt in Scipinia (Image 1E); in Scipinia the spines on dorsal side of head and pronotum are strong and long and the long spines in posterior pair of pronotum are bifurcate at tip (Image 2A) while in Irantha the spines on head and pronotum are small and none is bifurcate at tip (Image 3C). Abdomen is broadly similar but comparative images are not given as it is damaged in this specimen of Irantha.

Image 4 includes the dorsal (4A), ventral (4B) and lateral (4C) views of the syntype of Irantha armipes preserved in The Swedish Museum of Natural History, along with its labels (4D). The characters of this species are clearly observed in this well-preserved specimen studied by C. Stål. The lateral view shows the characters of spines on head and pronotum, labial segments and the nodulose and spiny fore femora very well. 
Distribution: Irantha armipes is known from India (Karnataka and several localities in southern India), Sri Lanka, and Nepal (Ambrose 2006, Bhagyasree 2018 checklist) but apparently it is so far not recorded from Assam.

\section{Discussion}

The two genera Irantha and Scipinia are closely related to each other and have similar body form and genital structure and may be synonymized in future, as sometimes it is difficult to assign the related species (Huang et al. 2007). We hope that the illustrations provided here will help to easily distinguish these two species found in India. Chen et al. (2005) have listed other related genera and commented on their narrow distribution while Huang et al. (2007) also pointed out that all species of Irantha are distributed only in the Oriental and Australasian Regions.

Das \& Ambrose (2007) studied bionomics of $I$. armipes (from specimens collected in Kanyakumari, Tamil Nadu) and gave several illustrations of adult and nymphal morphology. Das et al. (2010) studied predation of Helicoverpa by Scipinia, however, information about the bionomics of $S$. horrida is still unknown.

The distribution records of most insects found in India are rather poor; detailed, well-illustrated redescriptions of most species are also necessary as their identification is still problematic (Ghate 2013). Correct identification helps to authentically add to the record of distribution and also to the study of comparative aspects of bionomics or phylogeny.

\section{REFERENCES}

Ambrose, D.P. (2006). A checklist of Indian assassin bugs (Insects: Heteroptera: Reduviidae) with taxonomic status, distribution and diagnostic morphological characteristics. Zoos' Print Journal 21(9): 2388-2406. [With a separate supplement that gives checklist of species, etc.]. https://doi.org/10.11609/JoTT.ZPJ.871.2388-406
Bhagyasree, S.N. (2018). New records of the subfamily Harpactorinae (Reduviidae: Heteroptera : Hemiptera) from Karnataka. Journal of Entomology and Zoology Studies 6(1): 1293-1299.

Breddin, G. (1903). Neue Raubwanzen. Societas Entomologica 18: 3-5. Chen, W., P. Zhao \& W. Cai (2005). The discovery of the genus Irantha Stål, 1861 (Heteroptera: Reduviidae: Harpactorinae) from China, with the description of new species. Annales Zoologici 55(1): 107109. https://doi.org/10.3161/0003454053642130

Das, S.S.M. \& D. Ambrose (2007). Redescription, biology and behaviour of the Harpactorine assassin bug Irantha armipes (Stål) (Hemiptera: Reduviidae). Acta Entomologica Slovenica 16(1): 37-56. https:// www.zobodat.at/pdf/ActaEntSlov_16_0037-0056.pdf

Das, S.S.M., A.G. Kumar \& D.P. Ambrose (2010). Impact of intraspecific competition in the predation of the cotton bollworm, Helicoverpa armigera (Hübner) by Scipinia horrida (Stål) (Hemiptera: Reduviidae). Entomon 35(3): 203-208.

Distant, W.L. (1904). The Fauna of British India, including Ceylon and Burma. Rhynchota, 2 (Heteroptera). Taylor \& Francis, London, $371 \mathrm{pp}$.

Ghate, H.V. (2013). Challenges for taxonomy in Indian context. pages 60-66 In: V.P. Uniyal, V.P. \& A. Shrivastava (eds.) 2012. Arthropods and their Conservation in India (Insects \& Spiders), ENVIS Bulletin, Wildlife \& Protected Areas. Vol. 14, 2011. Wildlife Institute of India, 232pp.

Huang, X., P. Zhao, S. Zhou \& W. Cai (2007). A taxonomic review of genus Scipinia Stål (Hemiptera: Reduviidae: Harpactorinae) from China. Zootaxa 1507: 57-67.

Maldonado-Capriles, J. (1990). Systematic Catalogue of the Reduviidae of the World (Insecta: Heteroptera). Caribbean Journal of Science. Special publication No 1. University of Puerto Rico, Mayagüez, 694pp.

Mukherjee, P. \& M.E. Hassan (2016). Three new records of assassin bugs from Andaman and Nicobar Islands, India. Munis Entomology and Zoology 11(2): 573-575. https://www.munisentzool.org/yayin/ vol11/issue2/vol11issue2-6683160.pdf

Stål, C. (1855). Nya Hemiptera. Öfversigt af Kongliga Vetenskaps Akademiens Förhandlinger 12: 181-192.

Stål, C. (1861). Miscellanea hemipterologica. Entomologische Zeitung 22: 129-153.

Weirauch, C., J.-M. Bérenger, L. Berniker, D. Forero, M. Forthman, S.A. Frankenberg, S. A. Freedman, E. Gordon, R. Hoey-Chamberlain, W. S. Hwang, S. A. Marshall, A. Michael, S. M. Paiero, O. Udah, C. Watson, M. Yeo, G. Zhang \& J. Zhang (2014). An illustrated identification key to assassin bug subfamilies and tribes (Hemiptera: Reduviidae). Canadian Journal of Arthropod Identification 26(2): 1-115. https://doi.org/10.3752/cjai.2014.26

Zhao, P. (2008). Taxonomic Study on the Subfamily Harpactorinae (Heteroptera: Reduviidae) from China. Unpublished PhD Thesis, China Agricultural University, China. 

Dr. Albert G. Orr, Griffith University, Nathan, Australia

Dr. Sameer Padhye, Katholieke Universiteit Leuven, Belgium

Dr. Nancy van der Poorten, Toronto, Canada

Dr. Kareen Schnabel, NIWA, Wellington, New Zealand

Dr. R.M. Sharma, (Retd.) Scientist, Zoological Survey of India, Pune, India

Dr. Manju Siliwal, WILD, Coimbatore, Tamil Nadu, India

Dr. G.P. Sinha, Botanical Survey of India, Allahabad, India

Dr. K.A. Subramanian, Zoological Survey of India, New Alipore, Kolkata, India

Dr. P.M. Sureshan, Zoological Survey of India, Kozhikode, Kerala, India

Dr. R. Varatharajan, Manipur University, Imphal, Manipur, India

Dr. Eduard Vives, Museu de Ciències Naturals de Barcelona, Terrassa, Spain

Dr. James Young, Hong Kong Lepidopterists' Society, Hong Kong

Dr. R. Sundararaj, Institute of Wood Science \& Technology, Bengaluru, India

Dr. M. Nithyanandan, Environmental Department, La Ala Al Kuwait Real Estate. Co. K.S.C., Kuwait

Dr. Himender Bharti, Punjabi University, Punjab, India

Mr. Purnendu Roy, London, UK

Dr. Saito Motoki, The Butterfly Society of Japan, Tokyo, Japan

Dr. Sanjay Sondhi, TITLI TRUST, Kalpavriksh, Dehradun, India

Dr. Nguyen Thi Phuong Lien, Vietnam Academy of Science and Technology, Hanoi, Vietnam

Dr. Nitin Kulkarni, Tropical Research Institute, Jabalpur, India

Dr. Robin Wen Jiang Ngiam, National Parks Board, Singapore

Dr. Lional Monod, Natural History Museum of Geneva, Genève, Switzerland.

Dr. Asheesh Shivam, Nehru Gram Bharti University, Allahabad, India

Dr. Rosana Moreira da Rocha, Universidade Federal do Paraná, Curitiba, Brasil

Dr. Kurt R. Arnold, North Dakota State University, Saxony, Germany

Dr. James M. Carpenter, American Museum of Natural History, New York, USA

Dr. David M. Claborn, Missouri State University, Springfield, USA

Dr. Kareen Schnabel, Marine Biologist, Wellington, New Zealand

Dr. Amazonas Chagas Júnior, Universidade Federal de Mato Grosso, Cuiabá, Brasil

Mr. Monsoon Jyoti Gogoi, Assam University, Silchar, Assam, India

Dr. Heo Chong Chin, Universiti Teknologi MARA (UiTM), Selangor, Malaysia

Dr. R.J. Shiel, University of Adelaide, SA 5005, Australia

Dr. Siddharth Kulkarni, The George Washington University, Washington, USA

Dr. Priyadarsanan Dharma Rajan, ATREE, Bengaluru, India

Dr. Phil Alderslade, CSIRO Marine And Atmospheric Research, Hobart, Australia

Dr. John E.N. Veron, Coral Reef Research, Townsville, Australia

Dr. Daniel Whitmore, State Museum of Natural History Stuttgart, Rosenstein, Germany.

Dr. Yu-Feng Hsu, National Taiwan Normal University, Taipei City, Taiwan

Dr. Keith V. Wolfe, Antioch, California, USA

Dr. Siddharth Kulkarni, The Hormiga Lab, The George Washington University, Washington,

D.C., USA

Dr. Tomas Ditrich, Faculty of Education, University of South Bohemia in Ceske

Budejovice, Czech Republic

Dr. Mihaly Foldvari, Natural History Museum, University of Oslo, Norway

Dr. V.P. Uniyal, Wildlife Institute of India, Dehradun, Uttarakhand 248001, India

Dr. John T.D. Caleb, Zoological Survey of India, Kolkata, West Bengal, India

Dr. Priyadarsanan Dharma Rajan, Ashoka Trust for Research in Ecology and the Environment (ATREE), Royal Enclave, Bangalore, Karnataka, India

\section{Fishes}

Dr. Neelesh Dahanukar, IISER, Pune, Maharashtra, India

Dr. Topiltzin Contreras MacBeath, Universidad Autónoma del estado de Morelos, México

Dr. Heok Hee Ng, National University of Singapore, Science Drive, Singapore

Dr. Rajeev Raghavan, St. Albert's College, Kochi, Kerala, India

Dr. Robert D. Sluka, Chiltern Gateway Project, A Rocha UK, Southall, Middlesex, UK

Dr. E. Vivekanandan, Central Marine Fisheries Research Institute, Chennai, India

Dr. Davor Zanella, University of Zagreb, Zagreb, Croatia

Dr. A. Biju Kumar, University of Kerala, Thiruvananthapuram, Kerala, India

Dr. Akhilesh K.V., ICAR-Central Marine Fisheries Research Institute, Mumbai Research

Centre, Mumbai, Maharashtra, India

Dr. J.A. Johnson, Wildlife Institute of India, Dehradun, Uttarakhand, India

\section{Amphibians}

Dr. Sushil K. Dutta, Indian Institute of Science, Bengaluru, Karnataka, India

Dr. Annemarie Ohler, Muséum national d'Histoire naturelle, Paris, France

\section{Reptiles}

Dr. Gernot Vogel, Heidelberg, Germany

Dr. Raju Vyas, Vadodara, Gujarat, India

Dr. Pritpal S. Soorae, Environment Agency, Abu Dubai, UAE.

Prof. Dr. Wayne J. Fuller, Near East University, Mersin, Turkey

Prof. Chandrashekher U. Rivonker, Goa University, Taleigao Plateau, Goa. India

Dr. S.R. Ganesh, Chennai Snake Park, Chennai, Tamil Nadu, India

Dr. Himansu Sekhar Das, Terrestrial \& Marine Biodiversity, Abu Dhabi, UAE
Birds

Dr. Hem Sagar Baral, Charles Sturt University, NSW Australia

Dr. Chris Bowden, Royal Society for the Protection of Birds, Sandy, UK

Dr. Priya Davidar, Pondicherry University, Kalapet, Puducherry, India

Dr. J.W. Duckworth, IUCN SSC, Bath, UK

Dr. Rajah Jayapal, SACON, Coimbatore, Tamil Nadu, India

Dr. Rajiv S. Kalsi, M.L.N. College, Yamuna Nagar, Haryana, India

Dr. V. Santharam, Rishi Valley Education Centre, Chittoor Dt., Andhra Pradesh, India

Dr. S. Balachandran, Bombay Natural History Society, Mumbai, India

Mr. J. Praveen, Bengaluru, India

Dr. C. Srinivasulu, Osmania University, Hyderabad, India

Dr. K.S. Gopi Sundar, International Crane Foundation, Baraboo, USA

Dr. Gombobaatar Sundev, Professor of Ornithology, Ulaanbaatar, Mongolia

Prof. Reuven Yosef, International Birding \& Research Centre, Eilat, Israel

Dr. Taej Mundkur, Wetlands International, Wageningen, The Netherlands

Dr. Carol Inskipp, Bishop Auckland Co., Durham, UK

Dr. Tim Inskipp, Bishop Auckland Co, Durham, UK

Dr. V. Gokula, National College, Tiruchirappalli, Tamil Nadu, India

Dr. Arkady Lelej, Russian Academy of Sciences, Vladivostok, Russia

Dr. Simon Dowell, Science Director, Chester Zoo, UK

Dr. Mário Gabriel Santiago dos Santos, Universidade de Trás-os-Montes e Alto Douro,

Quinta de Prados, Vila Real, Portugal

Dr. Grant Connette, Smithsonian Institution, Royal, VA, USA

Dr. M. Zafar-ul Islam, Prince Saud Al Faisal Wildlife Research Center, Taif, Saudi Arabia

Mammals

Dr. Giovanni Amori, CNR - Institute of Ecosystem Studies, Rome, Italy

Dr. Anwaruddin Chowdhury, Guwahati, India

Dr. David Mallon, Zoological Society of London, UK

Dr. Shomita Mukherjee, SACON, Coimbatore, Tamil Nadu, India

Dr. Angie Appel, Wild Cat Network, Germany

Dr. P.O. Nameer, Kerala Agricultural University, Thrissur, Kerala, India

Dr. Ian Redmond, UNEP Convention on Migratory Species, Lansdown, UK

Dr. Heidi S. Riddle, Riddle's Elephant and Wildlife Sanctuary, Arkansas, USA

Dr. Karin Schwartz, George Mason University, Fairfax, Virginia.

Dr. Lala A.K. Singh, Bhubaneswar, Orissa, India

Dr. Mewa Singh, Mysore University, Mysore, India

Dr. Paul Racey, University of Exeter, Devon, UK

Dr. Honnavalli N. Kumara, SACON, Anaikatty P.O., Coimbatore, Tamil Nadu, India

Dr. Nishith Dharaiya, HNG University, Patan, Gujarat, India

Dr. Spartaco Gippoliti, Socio Onorario Società Italiana per la Storia della Fauna "Giuseppe

Altobello", Rome, Italy

Dr. Justus Joshua, Green Future Foundation, Tiruchirapalli, Tamil Nadu, India

Dr. H. Raghuram, The American College, Madurai, Tamil Nadu, India

Dr. Paul Bates, Harison Institute, Kent, UK

Dr. Jim Sanderson, Small Wild Cat Conservation Foundation, Hartford, USA

Dr. Dan Challender, University of Kent, Canterbury, UK

Dr. David Mallon, Manchester Metropolitan University, Derbyshire, UK

Dr. Brian L. Cypher, California State University-Stanislaus, Bakersfield, CA

Dr. S.S. Talmale, Zoological Survey of India, Pune, Maharashtra, India

Prof. Karan Bahadur Shah, Budhanilakantha Municipality, Kathmandu, Nepal

Dr. Susan Cheyne, Borneo Nature Foundation International, Palangkaraja, Indonesia

Dr. Hemanta Kafley, Wildlife Sciences, Tarleton State University, Texas, USA

\section{Other Disciplines}

Dr. Aniruddha Belsare, Columbia MO 65203, USA (Veterinary)

Dr. Mandar S. Paingankar, University of Pune, Pune, Maharashtra, India (Molecular)

Dr. Jack Tordoff, Critical Ecosystem Partnership Fund, Arlington, USA (Communities)

Dr. Ulrike Streicher, University of Oregon, Eugene, USA (Veterinary)

Dr. Hari Balasubramanian, EcoAdvisors, Nova Scotia, Canada (Communities)

Dr. Rayanna Hellem Santos Bezerra, Universidade Federal de Sergipe, São Cristóvão, Brazil

Dr. Jamie R. Wood, Landcare Research, Canterbury, New Zealand

Dr. Wendy Collinson-Jonker, Endangered Wildlife Trust, Gauteng, South Africa

Dr. Rajeshkumar G. Jani, Anand Agricultural University, Anand, Gujarat, India

Dr. O.N. Tiwari, Senior Scientist, ICAR-Indian Agricultural Research Institute (IARI), New

Delhi, India

Dr. L.D. Singla, Guru Angad Dev Veterinary and Animal Sciences University, Ludhiana, India

Dr. Rupika S. Rajakaruna, University of Peradeniya, Peradeniya, Sri Lanka

Dr. Bahar Baviskar, Wild-CER, Nagpur, Maharashtra 440013, India

Reviewers 2018-2020

Due to pausity of space, the list of reviewers for 2018-2020 is available online.
The opinions expressed by the authors do not reflect the views of the Journal of Threatened Taxa, Wildlife Information Liaison Development Society, Zoo Outreach Organization, or any of the partners. The journal, the publisher, the host, and the partners are not responsible for the accuracy of the political boundaries shown in the maps by the authors.

\footnotetext{
Print copies of the Journal are available at cost. Write to:

The Managing Editor, JoTT,

c/o Wildlife Information Liaison Development Society,

No. 12, Thiruvannamalai Nagar, Saravanampatti - Kalapatti Road,

Saravanampatti, Coimbatore, Tamil Nadu 641035, India

ravi@threatenedtaxa.org
} 


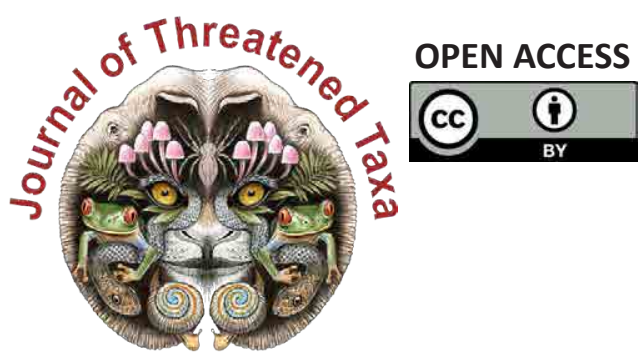

www.threatenedtaxa.org

The Journal of Threatened Taxa (JoTT) is dedicated to building evidence for conservation globally by publishing peer-reviewed articles online every month at a reasonably rapid rate at www.threatenedtaxa.org. All articles published in JoTT are registered under Creative Commons Attribution 4.0 International License unless otherwise mentioned. JoTT allows allows unrestricted use, reproduction, and distribution of articles in any medium by providing adequate credit to the author(s) and the source of publication.

\section{ISSN $0974-7907$ (Online) | ISSN $0974-7893$ (Print)}

\section{October 2021 | Vol. 13 | No. 12 | Pages: 19675-19886 \\ Date of Publication: 26 October 2021 (Online \& Print) DOI: 10.11609/jott.2021.13.12.19675-19886}

Articles

Roosting habits and habitats of the Indian Flying Fox Pteropus medius Temminck, 1825 in the northern districts of Tamil Nadu, India

- M. Pandian \& S. Suresh, Pp. 19675-19688

Diversity and distribution of avifauna at Warathenna-Hakkinda Environmental Protection Area in Kandy, Sri Lanka

- Dinelka Thilakarathne, Tithira Lakkana, Gayan Hirimuthugoda, Chaminda Wijesundara \& Shalika Kumburegama, Pp. 19689-19701

Grass species composition in tropical forest of southern India

- M. Ashokkumar, S. Swaminathan \& R. Nagarajan, Pp. 19702-19713

Communications

Habitat use and conservation threats to Wild Water Buffalo Bubalus arnee (Mammalia: Artiodactyla: Bovidae) in Koshi Tappu Wildlife Reserve, Nepal

- Reeta Khulal, Bijaya Neupane, Bijaya Dhami, Siddhartha Regmi, Ganesh Prasad Tiwari \& Manita Parajuli, Pp. 19714-19724

Get my head around owls: people perception and knowledge about owls of Andaman Islands

- Shanmugavel Sureshmarimuthu, Santhanakrishnan Babu, Nagaraj Rajeshkumar \& Honnavalli Nagaraj Kumara, Pp. 19725-19732

Abundance and diversity of threatened birds in Nangal Wetland, Punjab, India - Rajwinder Kaur \& Onkar Singh Brraich, Pp. 19733-19742

Evaluation of fish diversity and abundance in the Kabul River with comparisons between reaches above and below Kabul City, Afghanistan

- Ugyen Kelzang, Ahmad Farid Habibi \& Ryan J. Thoni, Pp. 19743-19752

New record of Myrmarachne melanocephala MacLeay, 1839 (Araneae: Salticidae) from Jharkhand, India and biogeographical implications of the co-occurrence of its ant model Tetraponera rufonigra Jerdon, 1851

- Rahul Kumar, Mirtunjay Sharma \& Ajay Kumar Sharma, Pp. 19753-19761

Diversity of spiders (Arachnida: Araneae) and the impact of pruning in Indian sandalwood plantations from Karnataka, India

-S. Padma 1 \& R. Sundararaj, Pp. 19762-19772

New records of cheilostome Bryozoa from the eastern coast of India encrusting on the exoskeleton of live horseshoe crabs of Indian Sundarbans

- Swati Das, Maria Susan Sanjay, Basudev Tripathy, C. Venkatraman \& K.A. Subramanian, Pp. 19773-19780

On the pteridophytes of Bherjan-Borajan-Padumoni Wildlife Sanctuary, Assam, India - Pranjal Borah \& Jayanta Barukial, Pp. 19781-19790

Population status of Heritiera fomes Buch.-Ham., a threatened species from Mahanadi Mangrove Wetland, India

- Sudam Charan Sahu, Manas Ranjan Mohanta \& N.H. Ravindranath, Pp. 19791-19798

Additions to the lichenized and lichenicolous fungi of Jammu \& Kashmir from Kishtwar High Altitude National Park

- Vishal Kumar, Yash Pal Sharma, Siljo Joseph, Roshinikumar Ngangom \& Sanjeeva Nayaka, Pp. 19799-19807

\section{Short Communications}

Is release of rehabilitated wildlife with embedded lead ammunition advisable? Plumbism in a Jaguar Panthera Onca (Mammalia: Carnivora: Felidae), survivor of gunshot wounds - Eduardo A. Díaz, Carolina Sáenz, E. Santiago Jiménez, David A. Egas \& Kelly Swing, Pp. 19808-19812

New record of the Sewing Needle Zipper Loach Paracanthocobitis linypha Singer \& Page, 2015 (Teleostei: Cypriniformes: Nemacheilidae) from the Chindwin drainage of Manipur, India

- Yumnam Rameshori, Yengkhom Chinglemba \& Waikhom Vishwanath, Pp. 19813-19817

Field identification characters to diagnose Microhyla mukhlesuri from closely related M. mymensinghensis (Amphibia: Microhylidae) and range extension of $M$. mukhlesuri up to West Bengal State, India

- Suman Pratihar \& Kaushik Deuti, Pp. 19818-19823
First report of Scipinia horrida (Stål) (Heteroptera: Reduviidae) from Assam, with comments on related genus Irantha Stål

- Anjana Singha Naorem, Santana Saikia, Anandita Buragohain, Rubina Azmeera Begum, Swapnil S. Boyane \& Hemant V. Ghate, Pp. 19824-19830

Flesh fly (Diptera: Sarcophagidae): male terminalia, diversity and expanded geographica distribution from India

- Kanholi Sreejith, Shuvra Kanti Sinha, Santanu Mahato \& Edamana Pushpalatha, Pp. 1983119836

Checklist of moths (Heterocera) of Tadong, Sikkim, India

- Prayash Chettri, Yuki Matsui, Hideshi Naka \& Archana Tiwari, Pp. 19837-19848

New distribution records of Begonia L., B. murina Craib and B. poilanei Kiew (Begoniaceae: Cucurbitales) for Laos

- Phongphayboun Phonepaseuth, Phetlasy Souladeth, Soulivanh Lanorsavanh, Shuichiro Tagane, Thyraphon Vongthavone \& Keooudone Souvannakhoummane Pp. 19849-19854

Notes

A recent sighting of the Stripe-backed Weasel Mustela strigidorsa (Mammalia: Carnivora: Mustelidae) in Hkakabo Razi Landscape, Myanmar

- Sai Sein Lin Oo, Tun Tun, Kyaw Myo Naing \& Paul Jeremy James Bates, Pp. 19855-19859

Are the uplifted reef beds in North Andaman letting nesting Olive Ridley Sea Turtle Lepidochelys olivacea stranded?

- Nehru Prabakaran, Anoop Raj Singh \& Vedagiri Thirumurugan, Pp. 19860-19863

First record of the orb-weaving spider Araneus tubabdominus Zhu \& Zhang, 1993 (Araneae: Araneidae) from India

- Souvik Sen, John T.D. Caleb \& Shelley Acharya, Pp. 19864-19866

The genus Catapiestus Perty, 1831 (Coleoptera: Tenebrionidae: Cnodalonini) from Arunachal Pradesh with one new record to India

- V.D. Hegde \& Sarita Yadav, Pp. 19867-19869

Rediscovery and extended distribution of Indigofera santapaui Sanjappa (Leguminosae: Papilionoideae) from the states of Maharashtra and Gujarat, India

- Kumar Vinod Chhotupuri Gosavi, Sanjay Gajanan Auti, Sharad Suresh Kambale \& Munivenkatappa Sanjappa, Pp. 19870-19873

Additional distribution records of Ceropegia anjanerica, an endemic and 'Endangered' lantern flower of the northern Western Ghats, India

- Samir Shrikant Maity, Ajay Natha Gangurde, Sharad Suresh Kambale, Avinash Ramchandra Gholave, Avinash Asraji Adsul, Ganesh Babaso Pawar \& Kumar Vinod Chhotupuri Gosavi, Pp. 19874-19877

Notes on the extended distribution of Impatiens megamalayana, a recently described balsam in Western Ghats, India

- Anoop P. Balan \& A.J. Robi, Pp. 19878-19883

Book Review

A look over on the scented tree of India (Santalum album) -S. Suresh Ramanan \& A. Arunachalam, Pp. 19884-19886
Publisher \& Host
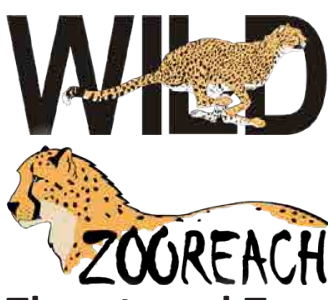

Threatened Taxa 